\title{
Creysse - Les Coutets
}

$n^{\circ} 026208$

\section{Milagros Folgado-Lopez}

\section{(2) OpenEdition}

Journals

Édition électronique

URL : http://journals.openedition.org/adlfi/16359

ISSN : 2114-0502

Éditeur

Ministère de la culture

Référence électronique

Milagros Folgado-Lopez, «Creysse - Les Coutets », ADLFI. Archéologie de la France - Informations [En ligne], Aquitaine, mis en ligne le 10 février 2016, consulté le 19 avril 2019. URL : http:// journals.openedition.org/adlfi/16359

Ce document a été généré automatiquement le 19 avril 2019

(c) Ministère de la Culture et de la Communication, CNRS 


\title{
Creysse - Les Coutets
}

$n^{\circ} 026208$

\author{
Milagros Folgado-Lopez
}

Lien Atlas (MCC) :

http://atlas.patrimoines.culture.fr/atlas/trunk/index.php?

ap_theme=DOM_2.01.02\&ap_bbox=0.527;44.844;0.584;44.887

1 Un diagnostic archéologique a été réalisée au lieu-dit les Coutets. Il concerne deux projets relatifs à la construction de logements. L'emprise se situe sur le versant nord du vallon des Coutets, dans un contexte riche en découvertes de la période paléolithique. Malgré ce contexte, un nombre très réduit de pièces lithiques $(n=55)$ ont été découvertes. Elles ont été prélevées dans un contexte sédimentaire de fortes colluvions pléistocènes au-dessus de dépôts érosifs tertiaires peu favorables à la conservation de concentrations lithiques.

2 La petite série lithique pourrait être attribuée au Paléolithique supérieur au sens large (plus particulièrement au Magdalénien pour un nucléus laminaire). Il faut toutefois signaler qu'un nucléus Levallois, attribuable sans conteste au Paléolithique moyen, a été aussi prélevé dans le même ensemble sédimentaire.

3 Sept structures ( 4 trous de poteau et 3 fossés), très probablement de période contemporaine ont également été observées. 
INDEX

Index chronologique : Paléolithique

Index géographique : Aquitaine, Dordogne (24), Creysse

operation Opération préventive de diagnostic (OPD)

\section{AUTEURS}

\section{MILAGROS FOLGADO-LOPEZ}

Inrap 